\title{
THE SEPARATION OF POWERS IN BRITISH JURISDICTIONS
}

\author{
W. Jethro Brown \\ - President, The Industrial Court, Adelaide, South Australia \\ PART I
}

The Yale Law Journal for February, r920, includes an article by Professor Green on the Separation of Governmental Powers. ${ }^{1}$ The subject is, in my opinion, of grave importance. The average elector is clamorous to get things done, and done right away, no matter how. His attitude is often reflected in a legislative sanction of administrative absolutism. In Australia, there has been a recent tendency to substitute administrative "discretion" for judicial process-at times even to stultify the judicature by appointing administrative commissions to inquire into the justice of judicial acts! Political appointments to the bench may be unavoidable; but their evils are mitigated by a system of appeals. Encroachments upon the Rule of Law open the way to irremediable abuses. The ever increasing complexity of state activities renders the recognition of the doctrine of the separation of powers not less but more important.

To the casual student of English law, the doctrine of the separation of powers might appear almost non-existent-a sort of calamity, or at best a metaphysical subtlety, reserved for countries which suffer from the possession of a written and rigid constitution. Happily the view is unfounded. While a statute of the Imperial Parliament cannot be challenged on the ground of usurpation, the doctrine in question is implicit (I) as a convention of the Constitution; (2) as a constitutional limitation upon the activities of organs of state subordinate to the Imperial Parliament; (3) as a rule of statutory construction which operates necessarily, if often unconsciously, upon the judicial mind when interpreting legislative enactments.

Professor Green states the doctrine from the point of view of an American lawyer. In the present article, I approach the doctrine from the point of view of English law as it exists in varying jurisdictions where the doctrine has a varying application. I divide the article into two parts. Part I includes some preliminary observations as to fundamentals, and an analysis of a leading English case. Part II will be devoted to an analysis of an Australian case which involves a consideration of the nature of the powers exercised by what is called an "Industrial Court," an institution which is interesting, not merely because it affords a searching test of the meaning and scope of the doctrine of the separation of powers, but also because the subject of the judicial or

${ }^{1}$ (1920) 29 Yale LAw Journal, 369. 
"quasi-judicial" settlement of industrial conflicts is associated with what is probably the most formidable problem of social life to-day.

The chief data to be considered in relation to the doctrine are Organ, Process (or the way in which the organ works), and Effect. For the purposes of this article, I shall speak of such data as "normal sequence." Speaking generally, when normal sequence is apparent, so far so good. When there is an apparent break in the sequence, the legal consequence depends upon the nature of the break, and the jurisdiction in which it takes place. In the discussion of such matters, it may be convenient at times to speak simply of organ and function, since under function both process and effect may be subsumed.

Does organ determine the nature of the function, or does function determine what is, or what should be, the structure of the appropriate organ? There exists in fact a differentiation in organs and a classification of functions. I submit that, for practical reasons, the traditional emphasis on function as determining what the organ is, or what it should be, is correct. In other words, if the question of the validity of the exercise of a power arises, the first thing to do is to inquire what is the nature of the functions. This involves a consideration both of process and of effect. Having once determined the nature of the function, we next ask the question whether the function is exercised by an appropriate organ. I do not suggest that we can always proceed on such lines. The function exercised may be at times of such an anomalous character that a reference to the structure of the organ will have value for the purpose of determining the nature of the function. But the general rule is the other way.

How are "Organs" and "Functions" to be defined? If the nature of an organ is to be ascertained, not by its name or even by its structure, but by reference to the functions which it exercises, the primary emphasis is thrown on the definition of Function. I submit that any attempt at a definition of either organ or function should be by reference to type. As Westlake once remarked, we ought not to make legal classification depend on verbal definition as if law were an exact science. "We should follow the practice approved in natural history, where classications are founded on likenesses to types." The types of governmental activity known respectively as legislation, administration, and adjudication, are easily understood, although in particular cases it may be difficult to draw the border line. The types are referred to in a familiar dictum of Marshall. Professor Green's article appeals to me as a learned expansion of that dictum. Obviously, the definition of different governmental functions should be broad enough to include incidentals. But they must be incidentals in a restricted sense. Otherwise, the doctrine of the separation of powers might be whittled away indefinitely. In the determination of incidentals, considerations both of practical necessity and of established usage are relevant. The legislature controls its own procedure. The judicature as a result of stare decisis may 
make law. These are cases of incidentals, speaking from the point of view of legal, and not from the point of view of sociological, analysis. I make this qualification, because, to take a concrete example, a decision of a court of law may be of much greater importance as laying down a rule for the future than as settling a particular controversy. A more difficult case is that of the exercise of apparently judicial functions by primarily administrative bodies. In an article in the LAw QUARTERLY Review for April I9I5 by Dicey, ${ }^{2}$ the learned writer dealt with two famous cases in point, and speaks of "the exercise of judicial or quasijudicial powers by government departments." It appears to me that the author was trying to evade the horns of a dilemma. If we use the term "judicial power," ought we not to say that for certain purposes the government department is a judicial organ of the state? Professor Willoughby ${ }^{3}$ speaks expressly of the "judicial powers of administrative bodies"-an apparent paradox. On the other hand, if we use the term "quasi-judicial," are we not guilty of a mere subterfuge, seeking to evade logical conclusion by adopting a phrase of convenient ambiguity? I shall return to the dilemma later on. I shall only assert here that we ought to make a definite choice between judicial and quasi-judicial, and that if we employ the latter term at all we ought to explain precisely what is meant.

From the foregoing general remarks, the conclusion follows that in speaking of the separation of powers, I mean by powers, not organs, not processes, not effects, but functions as inclusive of process and effect. I submit that much confusion has been caused by a failure to adhere consistently to this method. To say that the judicial power can do this or that is misleading. The judicial power is something that is done or can be done. To say that a particular process is an exercise of the judicial power is but a partial expression of truth. Process is something done in pursuance of, or in course of the exercise of, a power. What the nature of that power is depends primarily on effect and secondarily on process. In some cases reference may properly be made to the structure of the organ. By the doctrine of the separation of powers, I understand that the questions of the competence of an organ of the state, or the validity of acts in the nature of process, or the character of the effect produced, may depend, and must often depend, upon the existence or non-existence of normal sequence. I submit such conclusions as of general application, although the degree of elasticity in the doctrine of the separation of powers depends upon the law prevailing in different jurisdictions.

A South Australian Statute. An Act of 1856 to consolidate ordinances relating to the supreme court of South Australia ${ }^{4}$ constitutes

\footnotetext{
"Dicey, The Development of Administrative Laze in England (Igr5) 31 L. QUART. REv. I48.

${ }^{3}$ Constitutional Law (1910).

'Sec. I8.
} 
the governor general in executive council (with the exception of the attorney general or crown solicitor) to be a court of appeals with authority to hear appeals from the supreme court of the state where the sum in issue is not less than $£$ Ioo. By Act No. 15 of 1865 , the scope of the court of appeals is broadened so as to include all cases without any limitation as to the amount in issue. I quote the sections because they illustrate the power of a legislature with plenary authority to make the government of the day a judicial body for certain specific purposes. I am not aware that any proceeding has ever been taken under the sections. Their practical unimportance goes to show that the doctrine of the separation of powers is really based on the necessities of life in a highly organized modern community. From the point of view of organ structure, the administration at a particular time is ill adapted for the discharge of judicial functions. While the statute in question cannot be held ultra vires, it offends in substance what I have called normal sequence.

Executive Commissions of Inquiry. The nature of the functions exercised by an executive commission of inquiry further illustrates the preliminary remarks which I have made with respect to normal sequence. So long as such commissions act within certain limits, they exercise an incidental executive function. Beyond those limits, the competence of the commission, or the validity of its acts, may be challenged as involving a usurpation. The definition of the limits varies in different jurisdictions. But the general principle is clear. The Australian High Court has held that the power to inquire, and even to require testimony upon an inquiry, is not judicial power; that inquiry is incidental to legislation and administration as well as adjudication; and that what is non-judicial when exercised without coercive power does not change its nature when the information can be required. ${ }^{5}$ The same Court has held that a federal act could not validly authorize a royal commission to inquire into matters not within the executive or legislative power of the Commonwealth. ${ }^{6}$ "The power assumed to be exercised would not be properly incidental to the powers of the Commonwealth Government." The case subsequently went to the Privy Council, ${ }^{7}$ but the decision there is not relevant for immediate purposes. A more interesting case in point is Cock v. The Attorney General. ${ }^{8}$ The Supreme Court of New Zealand in this case held that an inquiry instituted by the Crown for the purposes of ascertaining whether an offence had been committed or by whom, or whether any penalty or forfeiture had been incurred, was an invasion of the judicial powers of the courts, even though the inquiry was not for the purpose of awarding any legal penalty. In order to

${ }^{5}$ Clough v. Leahy (1904, Austr.) 2 C. L. R. 139.

- Colonial Sugar Refining Co. v. Attorney General (1912, Austr.) I5 C. L. R. 182.

'[19r4] A. C. 237. Cf. Jethro Brown, The Nature of a Federal Commonwealth (I9I4) 30 L. QUART. REv. 30I.

(Ig09, C. A.) 28 N. Z. I. R. 405. 
understand the case, it is necessary to note that a New Zealand act, while conferring upon royal commissions a power to compel testimony, had been silent as to the power to issue the commission, or undertake the inquiry. In effect, the New Zealand court held that the power to compel testimony as conferred by statute existed only in those cases in which at common law a prerogative of inquiry existed; and also that the examination as well as the determination of matters of rights before extraordinary tribunals was within the mischief provided against by $42 \mathrm{Edw}$. III, c. $3{ }^{9}$ and the Act for the Abolition of the Star Chamber. ${ }^{10}$ The above mentioned cases illustrate the importance of distinguishing between (I) the right of inquiry; (2) the right to compel testimony on inquiry; (3) the right to impose a penalty for a refusal to testify. In a federal constitution, where the separation of powers is a constitutional limitation on the legislative power the third-mentioned right could not be validly conferred on an executive commission of inquiry. In a jurisdiction where Parliament has plenary powers, the right might be expressly conferred, but in the absence of manifest and incontrovertible legislative intent, the separation of powers would operate as a rule of statutory construction to inhibit the right. The right of an executive commission to insist that testimony be given might be validly conferred, even under a federal constitution, within limits which can be deemed as necessarily incidental to federal executive action. But beyond these limits, there exists a conflict of authorities. On general principles of normal sequence, I submit that federal courts should jealously guard against any meddling on the part of an executive body with matters which properly belong to the judicature.

"Quasi-judicial" Powers. The head note to Local Government Board v. Arlidge $e^{11}$ reads in substance as follows:

Sect. $x 7$ c. f. The Housing, Town Planning, etc. Act of Igog, authorizes the local authority to make a closing order in respect of a dwelling house in the district if it appears to be unfit for human habitation, and to determine such order on being satisfied that such dwelling house has been rendered habitable. "The owner of the dwelling may appeal to the Local Government Board against the order, and against a refusal to determine the same. By section 39, the procedure on such appeal shall be such as the Local Government Board may by rules prescribe, provided that the Board shall not dismiss any appeal without first holding a public local inquiry. Held, (I) that a properly authenticated order of the Local Government Board, dismissing an appeal under these sections, is not open to objection on the grounds that it does not disclose which of the officers of the Board actually decided the appeal; (2) that an appellant to the Local Board is not entitled, as of right, as a condition precedent to the dismissal of his appeal, either (a) to be heard orally before the deciding officer; or (b) to see the report made by the Board's inspector upon the public local inquiry.

\footnotetext{
( $(1368)$.

${ }^{10}{ }_{16}$ Car. I, c. 1o (1640). Cf. Moore, Commonwealth of Australia (2d ed. I910).

${ }^{11}[1915$, H. L.] A. C. 120.
} 
I may add to the above summary statement that, under an earlier Act, the power of the local authority in dealing with unsanitary dwellings was to apply to a court of summary jurisdiction for a closing order. The owner had a right of appeal to the Court of Quarter Sessions. The transference of a power from courts of law to a department of the administration involves an apparent departure from normal sequence. The instant case had come before the House of Lords on an appeal from a decision of the Court of Appeal. ${ }^{12}$ The decision of the Court of Appeal is summarised by Dicey in an article already referred to ${ }^{13}$ as follows: "The Local Government Board . . . is called upon to exercise judicial functions, or in other words jurisdiction; and hence" it "must, when acting as a judge, comply with the rules of judicial procedure." Hamilton, L. J., ${ }^{14}$ had given a dissenting judgment. The following dictum from his judgment, however, may be quoted:

"The Local Government Board here is a statutory tribunal, anomalous as compared with common law Courts, created by the Legislature for a special class of appeals and endowed by it with the power of formulating its own procedure."15

The language of each of the judgments well deserved scrutiny. As, however, the case went to the House of Lords, it is sufficient to deal with the judgments given in the higher tribunal. I will only state here that, according to my own reading of the judgments both in the Court of Appeal and in the House of Lords, the doctrine of the separation of powers, though not expressly formulated in precise terms, is yet obviously present to the minds of the learned judges. Differences in the language of the judgments, and in conclusions arrived at, arise, not from any conscious rejection of the doctrine, but from difficulties in its application in the interpretation and construction of a particular Statute passed by an omnicompetent legislature.

The question immediately before the House of Lords was whether the Statute, when conferring an apparently judicial power on a recognized administrative body, implicitly required that body to follow normal judicial procedure. The question was answered in the negative. This result might have been arrived at on different lines of argument:

A. (I) The Board is an administrative body. Therefore the function must be deemed to be administrative, and strict judicial process need not be followed.

B. (I) The nature of an organ is determined by its functions.

(2) Functions include process.

(3) Where an administrative body exercises by competent statutory authority a power which had been previously exercised by courts of law, but the process is to be exercised as the body shall by rules prescribe, the discretion as to

12 Constituted by Vaughan Williams, Buckley, and Hamilton, L. JJ.

${ }^{13}$ Supra note 2.

"Now Lord Sumner.

${ }^{15}$ [1914] I K. B. I60, 201. 
process implies that the function may be exercised in an administrative way, provided that the requirements of what may be called natural justice in a popular sense are complied with.

C. (I) The effect aimed at by a determination of the Local Government Board on an appeal is in character judicial-a final and authoritative adjudication as to private rights.

(2) The process should therefore be judicial; and the Board is pro tanto a judicial organ of State.

(3) Since, however, an omnicompetent Parliament has authorized the department to prescribe rules of its own as to process, the process, if in accordance with those rules, is judicial process even though not conforming to ordinary rules of procedure as established in ordinary civil courts.

All judgments given in the case by the House of Lords converge to a single result. But, as I have tried to show, that result might have been arrived at in at least three different ways. The differences may seem negligible except from the point of view of an abstract jurisprudence. This is not, however, the case. Combinations of fact are infinite, and the precise scope or degree of the authority of a precedent varies according to the way in which the rule of law' necessarily implicit in the precedent should be stated. Where, however, there are four distinct judgments, the problem of how best to express the ratio decidendi may tax or defy the most subtle analysis. On a first view of the instant case, alternative $\mathrm{A}$ seems to approximate most closely to the net resultant, although many dicta suggest alternative $B$; alternative $C$ is unsupported. Why? The Imperial Parliament is quite competent to endow a normally administrative body with judicial powers. It cannot be questioned that the power conferred was the same from the point of view of effect as that previously exercised by courts of law adopting ordinary judicial process. Was the nature of the power changed when conferred on a government department? If the Local Government Board had prescribed rules in general accord with ordinary judicial procedure, would not the Board have been recognised by the House of Lords as being pro tanto a court of law, though of limited and peculiar jurisdiction? If so, the power exercised would be a judicial power. Would the power be altered in its nature because exercised in accordance with rules which, though not in conformity with the usage of established courts, were revertheless designed to insure (and were, according to the learned Judges, required by the Act to insure) that the matter should be dealt with in a "judicial temper." The emphasis which was placed on the mere fact that the respondent had been given full opportunity to protect his interests is, in itself, suggestive.

I do not criticise the decision of the House of Lords in the instant case. I merely state questions which, while assuming the justice of the decision, are designed to suggest that the decision might have been arrived at in another way from that actually chosen. The consideration of such questions may help to prepare the way for a statement of 
the rules of law actually implicit in the case. From the language of the various judgments, it appears to me that the judges held that a power once judicial had become administrative-a conclusion which appears to challenge a familiar principle, sometimes regarded as axiomatic, that the nature of a power is not affected by the person or body which exercises it. Whether I am justified in drawing the conclusion is a question which may be answered by reference to certain dicta.

"T doubt," says Haldane, L. C., at p. ' 344 , "whether it is correct to speak of the case as a lis inter partes. The Hampstead Borough Council was itself acting administratively, although it had the right to appear, and did appear, before the inspector, and on the appeal, and might have to pay or receive costs."

Per Lord Shaw of Dumfermline:

"The judgments of the majority of the Court below appear to me, if I may say so with respect, to be dominated by the idea that the analogy of judicial methods or procedure should apply to departmental action. Judicial methods may, in many points of administration, be entirely unsuitable, and produce delays, expense, and public and private injury. The department must obey the statute. For instance, in the present case, it must hold a public local inquiry, and upon a point of law it must have a decision of the Law Courts. Quoad ultra it is, and if administration is to be beneficial and effective, it must be the master of its own procedure. .... When a central administrative board deals with an appeal from a local authority it must do its best to act justly, and to reach just ends by just means. If a statute prescribes the means it must employ them. If it is left without express guidance it must still act honestly and by honest means. In regard to these certain ways and methods of judicial procedure may very likely be imitated; and lawyerlike methods may find especial favor from lawyers. But that the judiciary should presume to impose its own methods on administrative or executive officers is a usurpation." (pp. I37-8.)

Per Lord Parmoor, at p. I43:

"If I thought that this non-disclosure deprived the respondent of a fair hearing in accord with the terms of substantial justice, I should accede to the argument on behalf of the respondent, and should hold the same view whether the appeal is to be regarded as a quasi-judicial act or as a decision on review of the administrative action of the local authority. I am unable, however, to come to any such conclusion, and doubt whether assistance is to be gained from arguments based on analogous cases."

Pér Lord Moulton, at pp. I46-r 50:

"I have no doubt that the new procedure as to appeal was intended to be an appeal to a superior executive body as such, and that it was not intended that the Local Government Board should act in a purely judicial capacity. There is no doubt that it must act 'in a judicial temper.' Its order might confirm an order of the local authority interfering with the property of a private individual, and thereupon that order would be capable of legal enforcement. In the exercise of such powers the Local Government Board would be bound to treat the matter in a judicial spirit, availing itself of its wide powers solely for the purpose of carrying into effect in the best way the provisions of the Act. ... The 
Legislature has provided an appeal, but it is an appeal to an administrative department of State and not to a judicial body. It is said, truthfully, that on such an appeal the Local Government Board must act judicially, but this, in my opinion, only means that it must preserve a judicial temper and perform its duties conscientiously, with a proper feeling of responsibility, in view of the fact that its acts affect the property and rights of individuals. Parliament has wisely laid down certain rules to be observed in the performance of its functions in these matters, and those rules must be observed because they are imposed by statute, and for no other reason, and whether they give much or little opportunity for what I may call quasi-litigious procedure depends solely on what Parliament has thought right. These rules are beyond the criticism of the Courts, and it is not their business to add to or take away from them, or even to discuss whether in the opinion of the individual members of the Court they are adequate or not."

Bearing the above dicta in mind, I can only come to the conclusion that, in the view of the House of Lords, the nature of the power itself was changed by the fact of its transference to an administrative body empowered to act in accordance with rules which it should frame. This is not inconsistent with the view already stated that we should argue from function backwards to the nature of the organ. While function determines the nature of the organ, function includes process. If an absolute legislature leaves the nature of the process to an administrative organ, that organ may be within its rights in adopting administrative process. When it can do so, and does do so, the function is administrative and not judicial. The organ is, therefore, still administrative even when exercising the function in question. The duty of the House of Lords was to give effect to the intent of a particular statute. In the endeavour to discharge this duty the ultimate court of appeal was evidently influenced by two outstanding facts. First, the power had been transferred to a normally administrative body. Second, that body was expressly authorized to make rules of its own as to process. We are not entitled to infer as a matter of course that the first of these facts would have been alone sufficient to change the nature of the power exercised from judicial to administrative. The legislature might have created the Local Government Board a judicial organ for certain purposes - either expressly or by implication. It was held not to have done so. The decision is not in conflict with the general argument of this article. Indeed, I have expressly stated that the structure of an organ may, in certain cases, be relevant for the purpose of ascertaining the nature of a function exercised, though as a general rule the function determines the nature of the organ. If a statute similar to that under consideration in the instant case had been an Act of Congress, several conclusions are possible. One is that the American courts would have held the statute ultra vires. In the instant case, the House of Lords could not have held the statute ultra vires. But that the doctrine of the separation of powers was not ignored is apparent throughout the several judgments. The actual decision might have been arrived at by 
holding the Local Government Board a judicial organ pro tanto, with a process of its own. The Court preferred the other alternative of holding that the legislature had intended to endow the Local Government Board with novel administrative functions-functions which, though they must be discharged in a judicial temper, were not judicial. On the whole, it appears to me that the doctrine of the separation of powers is more rather than less honoured by refusing to recognize either that the Board was a judicial organ pro tanto or that the power of the Board in the exercise of its novel function was judicial. The doctrine in question, as applied to Imperial Acts, is not a constitutional limitation, but a rule of statutory construction. Being such, it must not override legislative intent, though it is relevant for expressing in a legal way what the intent amounts to. One apparent result of such expression is that a decision of the Board on an appeal, though it may be "judicial" for the purposes of certiorari, is not a judgment in the strict sense of the term. It is true that, as I have pointed out, from the point of view of effect, the decision of the Board conforms in its essential aspect with a judgment of a court of justice. But this alone is not conclusive, since there are many cases of determinations of bodies, not courts, which are binding and conclusive. The distinction, though apparently formal; may have important results. Another conclusion is that, since the power exercised by the Board is but quasi-judicial, the positive assertion that strict judicial procedure need not be complied with suggests the negative implication that the Local Government Board, in the exercise of process, has not all the powers, privileges, and immunities which can be claimed as incidental to strict judicial process. When once it is clear that the decision of the House of Lords amounts in substance to a decision that the nature of the power once exercised by courts of law is now administrative, it will be apparent that many developments, at present unforeseeable, may result in the future as new cases come before courts of law for adjudication and determination.

PART II

Industrial courts. In Part I of the present article, I insisted upon the importance of distinguishing between organ, process, and effect. I described these as "normal sequence." I said, inter alia, that where normal sequence is apparent, so far so well; but that where there is a break in the normal sequence, the legal consequences must depend upon the nature of the break, and the law prevailing in the jurisdiction in which the break takes place. I proceeded to give some illustrations, and in particular I endeavored to state the rule of law implicit in the case of Local Government Board v. Arlidge. ${ }^{16}$

In the present Part, I illustrate the doctrine of the separation of powers by reference to the nature of the powers exercised by what are called Industrial Courts. Such courts exist in England and Austral-

\footnotetext{
${ }^{16}$ Supra note Ir.
} 
asia $;^{17}$ their powers vary, being sometimes legislative, at other times or places, judicial or administrative. For the purposes of the present article, however, I propose to consider the nature of the Industrial Court as constituted in a jurisdiction where the doctrine of the separation of powers is formally recognized as a constitutional limitation on legislative power. This limits me to the Commonwealth Court of Conciliation and Arbitration. The application to American conditions of any conclusions at which I may arrive might need to be qualified here and there, but the general principles underlying the doctrine of the separation of powers are applicable alike in the Commonwealth and in the United States. It so happens that the nature of the power exercised by the Commonwealth Court of Conciliation and Arbitration has been the subject of a recent leading case, ${ }^{18}$ I propose to consider that case, with a few preliminary remarks for the purpose of explaining the constitutional powers of the Commonwealth Parliament.

By the Commonwealth Constitution ${ }^{19}$ the Parliament of the Commonwealth has power to make laws for the peace, order, and good government of the Commonwealth with respect to conciliation and arbitration for the prevention and settlement of industrial disputes extending beyond the limits of any one state. The power thus expressly given might be implied, in whole or part, from other clauses of the Commonwealth Constitution. The point need not be discussed here. In Chapter III of the Constitution, "The Judicature," the Parliament of the Commonwealth may constitute federal courts, but the judges of such courts are to be removable only by the Governor in Council on address of both Houses of Parliament. In pursuance of the powers conferred by the Constitution, the Parliament of the Commonwealth has passed Conciliation and Arbitration Acts purporting to create a Court of Record to consist of a President (selected from Justices of the High Court) and entitled to hold office for seven years. The Court is to have cognizance of industrial disputes properly submitted to it by. plaint; it has power to determine disputes by an "award," enforceable for a period not exceeding five years; and it may. impose obligations of an onerous character on either party. In particular, the Court has power to make any order and give any direction in pursiance of the hearing or determination, to fix maximum penalties for any breach or non-observance of an order or award, to impose penalties up to such maximum, to order compliance with any order or award, and to grant mandamuses or injunctions.

In the instant case the High Court of the Commonwealth was called upon to consider the following questions:

(I) Is the constitution of the Commonwealth Court of Conciliation

${ }^{17}$ And in Kansas. See Vance, The Kansas Court of Industrial Relations and Its Background (I92I) 30 YALE LAW JoURNAL, 455.

${ }^{18}$ Waterside Workers' Federation v. Alexander (19r8, Austr.) 25 C. L. R. 434.

${ }^{19}$ Ch. I, "Parliament," sec. 5I, pl. xxxv. 
and Arbitration beyond the powers of the Parliament of the Commonwealth, and in particular as to (a) the arbitral provisions; (b) the enforcing provisions?

(2) Is the award invalid by reason of the appointment of the President for seven years only?

(3) Is the award enforceable by the said Court? Answers:

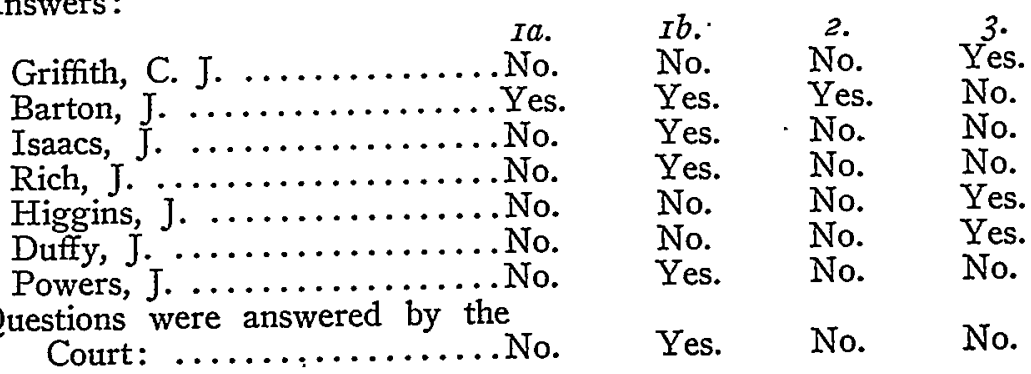

The foregoing table suggests an interesting divergence of views. In fact the divergence is greater than appears. Two judges gave answers in alternative to those stated, and, while six judgments were given, the lines of argument by which "Yes" or "No" was arrived at were often, if not in actual conflict, at any rate suggestive of judicial dissonances.

At the outset I may remark that the term "Arbitration" in pl. $x x x y r$ of the Commonwealth Constitution is wide enough to include compulsory arbitration as distinct from voluntary submission to an umpire. Several years before the enactment of the Commonwealth Constitution by the Imperial Legislature, acts had been passed in Australian states embodying the principle of compulsory arbitration. A South Australian $\mathrm{act}^{20}$ includes Pt. VI- "Compulsory Conciliation," Pt. VII-“Enforcement of Awards and Agreements." An even more comprehensive act was passed in the same year by the New Zealand legislature. The act provided for boards of conciliation and a court of arbitration. It defined the structure and status of the court, its jurisdiction, process, and the means of enforcement of awards. While the acts mentioned may have introduced a new method of settling industrial disputes, they do not involve a violation of usage as regards the scope of the term. "Arbitration." In Lord Halsbury's "Laws of England" the subject of "Arbitration" includes Pt. I-"References by consent out of court;" Pt. II-_References under order of the Court;" Pt. III-"References. under Act of Parliament." References by consent out of court, even at common law, must be determined in a quasi-judicial manner. The English Arbitration Act of 1889 supplemented the common law in various ways. Turning to references under order of court, the powers of the referee or arbitrator are thus defined:

"The referee ... is deemed to be an officer of the Court, and has such powers as are prescribed by the rules of Court, and, subject thereto, as the Court or judge may direct. Subject to any order made by the

${ }^{20}$ No. 598 of 1894 . 
Court or judge, he has the same authority in the conduct of the reference as a judge of the High Court. He may order discovery and production of documents, and may grant a commission to examine witnesses abroad; he may make an order for the inspection of property and for the addition of parties who ought to have been joined; and may direct judgment to be entered for any party. A referee or arbitrator to whom a reference for trial is ordered has no power to commit any person to prison, or to enforce any order by attachment or otherwise."

From the foregoing it will be apparent that under the Commonwealth Constitution, the Commonwealth Parliament was entitled to constitute(I) a tribunal of conciliation; (2) a court of compulsory arbitration. Under the former power, the Parliament might have created a tribunal or official unpire for hearing cases voluntarily submitted to it by the consent of both parties agreeing to submit their dispute and to be bound by an award. In such cases there need be no exercise of the judicial power stricto sensu, although the tribunal or officer would be required to act in a quasi-judicial manner. But the Commonwealth Parliament had also the power, as has been said, to create a court of arbitration. From the summary reference to the provisions of the Conciliation and Arbitration Acts, it is apparent that the Parliament did design to create a court of arbitration. The arbitration is compulsory; an action in respect of a breach of an award is not an action ex contractu; the factum is the award; the award is in the nature of a judgment binding parties inter $s e$; the court is called a Court of Record; it is empowered to make Rules of Court; it-is apparently designed to follow judicial process. Further, it acts in personam; and is authorized to enforce its own awards. Prima facie, there is a clear intent to create a judicial organ, though whether that judicial organ would be a "court exercising judicial power of the Commonwealth" may well be another matter. The outstanding fact is that the Conciliation and Arbitration Acts were designed to give to employers and employees a definite legal right to have their differences adjudicated. As had been remarked in an earlier case in a judgment by Isaacs and Rich, JJ., the position of industrialists has been gradually changing in recent decades from one of pure contract to one of status. ${ }^{21}$ The Conciliation and Arbitration Acts, under consideration in the principal case, are a very striking illustration.

I am not concerned here to discuss the justice of the decision of the Court in the instant case, but to illustrate the application of the doctrine of the separation of powers. As far as the decision itself is concerned, I may as well express at once my adherence to the following propositions:

(I) If the Court could enforce its own awards, it would be pro tanto a federal court exercising a part of the judicial power of the Commonwealth within the meaning of Chapter III of the Constitution.

(2) Chapter III, by what appears to me reasonable implication,

${ }^{2}$ See Federated Employees' Union v. City of Melbourne (I9I9, Austr.) 26 C. L. R. 508, 555 . 
requires that a judge of a federal court shall enjoy a life tenure as a judge of that court, subject to removal on address of both houses. The implication is not, however, so clear and necessary as to preclude conclusively the possibility that Parliament may have thought otherwise. Indeed, Griffith, C. J., in the instant case, did think otherwise.

(3) As the tenure of the President of the Court was for seven years only, the Court as in fact constituted could not enforce its own awards.

The above propositions accord with the majority decision of the High Court in the instant case. But they give rise to two questions. (a) Are the provisions of the Act relative to arbitration severable from the provisions relative to the enforcement of awards when made? (b) Is the President of the Court, when making an award which he may not enforce, assuming to exercise a judicial power? I shall assume, for the sake of argument, that the first question can be answered in the affirmative. The second question is the only one I propose to consider. I shall do so at some length because my answer is not in accord with the decision of the Court in the instant case. As, however, I am concerned in the present article only to illustrate the doctrine of the separation of powers, I shall refrain from comment on many dicta in the judgments of the learned judges which, however questionable they appear to me to be, are not relevant to the doctrine under consideration.

As I have already stated, the consideration of the nature of a power involves what I have called normal sequence-an analysis of structure of the organ and of the nature of a function as revealed in process and effect. The structure of the Commonwealth Arbitration Court is apparently judicial. The process is apparently judicial, consisting as it does of citation of parties, the hearing of argument and evidence, and the delivery of a judgment inter partes. Indeed, as ancillary to the exercise of the arbitral function the President of the Court has normal judicial powers in interlocutory proceedings, may order discovery, award costs, etc. But a conclusion that the power exercised in compulsory arbitration is per se, and apart from the power of the arbitrator to enforce his award, judicial, may be challenged on four possible grounds: (I) That an award operates on the future relations, pro tanto resembling legislation. (2) That an award prescribes a rule of conduct, again resembling legislation. (3) That an award creates new rights rather than interprets existing rights, once again resembling legislation. (4) That the duty imposed by an award may only be enforced by some other court than the court making the award.

As regards these grounds-all of which relate mainly to effect-the first and second, taken by themselves or even together, are negligible. 22 Indeed, every judgment, though it may not prescribe a rule of conduct, operates to create new rights, though these rights are not typically, as in the case of legislation, new independent rights. Further, as regards

${ }^{23} \mathrm{Cf}$. A maintenance order; some declaratory judgments; a decree of specific performance; etc. 
an award, if by express or implied authority of the Legislature an award may be made retrospective (if only to the date of the filing of the plaint), the nature of the power exercised by an arbitration court would not be affected in substance. Again, I attach no conclusive value to the possibility that the enforcement of an award may be left by a sovereign legislature to some other tribunal than the tribunal which makes the award. In the instant case, however, the Commonwealth High Court had to consider the nature of the power exercised by a tribunal expressly authorized to enforce its own awards. Assuming, as I have assumed, that, through a constitutional limitation, the tribunal could not so enforce, would the nature of the chief power exercised by the tribunal (the settling of industrial disputes) be altered because the supplemental provisions relating to enforcement could only be operated by courts of summary jurisdiction? I apprehend that a legislature is quite competent to create a court, while leaving the enforcement of the judgments of that court to inferior tribunals. The inability to enforce might have a value as suggestive of an intent on the part of the legislature to create a merely "quasi-judicial" tribunal. But such intent, as regards the instant case, is rebutted by express language to the contrary. I must refer, however, to a dictum, quoted in the instant case, of $\mathrm{Mr}$. Justice Miller of the Supreme Court of the United States; judicial power "is the power of a Court to decide and pronounce a judgment and carry it into effect between persons and parties who bring a case before it for decision."23 I submit that the definition in question, while good as a general description, is misleading if taken as of universal application..$^{24}$ If the organ be apparently judicial in structure, if the process is also apparently judicial, the power exercised may be judicial though the court is not expressly authorized to enforce its judgments, provided it is clear, as was generally conceded in the instant case, that the sovereign will enforce the judgment through the agency of courts of summary jurisdiction. As students of private international law will readily appreciate, questions of the making of judgments, and the enforcement thereof, have frequently to be distinguished. The test is rather that of res judicata. The real difficulty, therefore, centers around the third objection. The function of judges to declare law by a process of pure interpretation of existing law is often suggested as a decisive test of the judicial power. But, as I have already remarked, some bodies interpret law though they are not judicial bodies. Indeed, every administrative body has to do a certain amount of interpretation of law in the exercise of administrative functions. On the other hand, courts make new law while affecting to expound existing law. I submit three propositions as immediately relevant:

\footnotetext{
${ }^{25}$ Miller, Lectures on the Constitution (I89I) 314.

"As it proved to be in a recent Michigan case, which held the declaratory judgment unconstitutional, because it was not an exercise of judicial power. Anway v. Grand Rapids Ry. (I920) 2II Mich. 592, I79 N. W. 350. See Comments (I920) 30 YaLE LAW JournaI, I6I.
} 
(I) Historically there is good authority for saying judicial decisions precede law rather than follow it. Themis precedes Themistes. But without going to the historical origins of judicial decisions, courts of common law, while affecting to apply ancient custom, frequently gave rise to new custom.

"Above all local customs," declare Pollock and Maitland, in speaking of justice under the Norman Kings, "rose the custom of the King's Court. The jurisprudence of this court, if one may use so grand a phrase, was of necessity a flexible, occasional jurisprudence, dealing with an unprecedented state of affairs, meeting new facts by new expedients, wavering as wavered the balance of power between the king and his barons, capable of receiving impressions from without, influenced by the growth of Canon Law, influenced perhaps by Lombard learning, modern in the midst of antique surroundings. ... It was not a jurisprudence that had been transplanted from Normandy, but it had been developed by a court composed by Frenchmen to meet cases in which Frenchmen were concerned. . . . The future was to make the jurisprudence of the King's Court by far the most important element in the law of England." 25

Courts of equity, when the development of common law failed to reflect changing social and economic circumstance, followed a like line of procedure. Few chapters in English legal history are more interesting than that which shows how, step by step, the obligation of the feoffee to uses was first enforced as against the feoffee, and subsequently, step by step, against heirs, assignees, etc., until the point was reached when the use could be enforced against everyone except a bona fide purchaser for valuable consideration without notice of the use. Alike in common law and in equity, the judicial organ is a court of justice. The authority attached by the court to custom or precedent may vary: the unchanging characteristics of the court are a judicial process and a final determination of the rights and duties of parties.

(2) The view that judges only interpret and do not make law is even to-day a fiction. Private international law is largely the result of judicial decisions. The constitutional law of the Commonwealth is largely made by decisions of the High Court. In The Austinian Theory of Law I write : ${ }^{26}$

"It is a relief to turn from discussing the origin and disadvantages of an ancient fiction to consider more in detail how, as a matter of fact, judges act in dealing with cases not governed by pre-existing rule. In the first place, they do not necessarily refuse to decide the case by reference to the simple principle of holding for the defendant. In the second place, they reveal in their judgments, not merely the influence of ancient and established ideas and beliefs, but also the influence of a Time Spirit, thereby giving expression to rules which are new, both in the sense that they have not found expression in an earlier case, and in the sense that they could not have done so. So far, however, there is no claim to 'make new law. The function of the judges being to decide disputes in accordance with law so far as that may be possible,

${ }^{25}$ I Pollock \& Maitland, History of English Lare (2d ed. r899) 85, 86.

${ }^{20}$ (I906) 296, 297. 
but in any case somehow-in short, to administer justice-the mere fact that they apply a rule does not of necessity make that rule a part of the law. Comparatively early in English legal history, however, judges elected to be bound by precedents, not with the idea of magnifying the judicial office, but rather with the idea of limiting the judge. The discretion of the single judge was qualified by the necessity of deciding in harmony with the decisions of predecessors. As a result of the adoption of this principle, legal decisions give rise to new law. So general rules, legal conceptions, and principles are reached through a long series of decisions slowly working towards conclusions which at first were felt dimly or not at all. The older law is vivified by the infusion of elements drawn from the social life. Usage and opinion, social aspiration and economic needs, react upon the older law, adapting its texts, modifying their operation, developing their content, restraining, amplifying, and controlling in a thousand subtle and invisible ways."

As the body of law increases, the interpretive function becomes more and more important; but it still remains an absurd fiction that the judicial power only involves the interpretation and application of existing law.

"If we are to have a theory of the position of the magistrate or judge," writes Bryce, ${ }^{27}$ "... we must call him the recognized and permanent organ through which the mind of the people expresses itself in shaping that part of the law which the State Power does not formally enact."

There are, of course, important distinctions which normally distinguish judge-made law and law made by an enacting body. A normal judicial organ (omitting rules of court) makes law incidentally to the determination of a dispute or matter. It interprets rights which are assumed to be conferred by pre-existing law or the spirit of pre-existing law, that is to say, it operates retrospectively, as well as prospectively. Its primary function is to settle a dispute or matter-the law-making is a by-product. It is, of course, subject to legislative control. It may claim the power, but does not usually exercise the power, of reviewing its previous declarations of the law. Its laws have to be gathered, not from formal statements or principles, but from a decision, and often a number of judgments, in which the legal decision is embedded. On the other hand, a law-enacting or legislative body (a) avowedly imposes new law; (b) does so by way of legislative as distinct from judicial process; and (c) expresses a will for the purpose of binding other than parties to a dispute or matter. In the first part of the present article, when speaking of the definition of powers, I spoke of the logical necessity of definition by reference to types. The immediately preceding remarks indicate typically the powers known respectively as adjudication and legislation.

(3) So far as courts of compulsory arbitration are concerned, it can be said with truth that, quite apart from principles they may adopt when framing awards, and quite apart from any powers of enforcement

\footnotetext{
${ }^{27}$ Bryce, Studies in History and Jurisprudence (I901) 272.
} 
that they may or may not have, those courts necessarily interpret the industrial legislation which controls their action. They have also to interpret the rules of court which they are empowered to make, and which, when made, have a statutory force. Incidentally to the foregoing, the industrial arbitration courts have to interpret a great deal of common law which is of necessity read into the industrial legislation and the rules of court. Further, industrial courts have to interpret and apply principles which have been laid down in previous cases. The modern Parliament is oft abused; but it would savour of Contempt of Parliament to assume that it could have supposed that industrial peace and stability could be attained other than by the gradual development of a code of rules governing industrial relations. The code is progressive; but so much is said by Jessel, M. R., and other judges of the common law. The code of industrial law, like the civil code, broadens from precedent to precedent. Each new award expressly or implicitly contributes to it, and controls or limits the area of apparently unlimited discretion. I say "apparently unlimited" because I have in mind the fact that every award necessarily takes note of custom, just as commonlaw courts did. The industrial court gives a binding force to custom if the custom be reasonable-a requirement not unknown in the case of customary law in the civil courts. In any case, more and more, by the very nature.of things, awards must tend to become merely an application of principles, previously affirmed, to circumstances of time, place, and occupation. Again, compulsory arbitration, whatever tribunal may enforce the award when once it is made, is an interpretation of a new right conferred by statute. The new right is in accordance with a dictum in a conclusion of Isaacs and Rich, JJ., in an earlier case already referred to. ${ }^{28}$ "The position of the industrialists ... has been gradually changing from one of pure contract to one of status." In the interpretation of the new status, circumstances both of public policy and of customary observance, of social and economic needs, blend with, or are taken up in, the course of the discharge of the arbitral function. A legislature which avowedly creates a court of record empowered to arbitrate compulsorily, may not necessarily have read a familiar statement of Holmes, J.; but the statement deserves quotation, since its substance may be assumed not to have been beyond the ken of legislatorial knowledge. ${ }^{29}$

"The life of the law has not been logic: it has been experience. The felt necessities of the time, the prevalent moral and political theories, intuitions of public policy, avowed or unconscious, even the prejudices which judges share with their fellow-men, have a good deal more to do than the syllogism in determining the rules by which men should be governed."

The fact that courts of arbitration in the exercise of arbitral functions appear as creative of new law rather than interpretive of established law

${ }^{23}$ Silpra note 21 .

* Holmes, The Common Law (I88I) I. 
is an incident of an early stage of compulsory arbitration in industrial matters; and it must be a transitional stage if industrial courts are to function as an organ of the community for the promotion of industrial stability and social justice. The alternative to the progressive establishment of the reign of law in industrial relations is, under modern conditions, the dominance of unregulated. might. ${ }^{30}$ We cannot assume that Parliament supposed that the interpretation of the new status conferred would continue indefinitely along the lines of a mere caprice. When a new award is made, it creates no new independent right, but only gives form and substance to the right or status implicitly conferred by statute, and judicially expanded from time to time, by industrial courts. One is indeed reminded of the difficulties with which the Supreme Court of the United States has been confronted in interpreting the Anti-trust Acts, and the emphasis laid on the Rule of Reason. Of course, when the legislature enacts a policy, the details of that policy may be left to an administrative body. In such a case we have an illustration of administrative power as ancillary to legislation. When, however, the powers are vested in a body called a court of record empowered to make binding rules of court, designed to follow judicial process and to give a judgment which is a binding, final and conclusive determination between the disputants who litigate before it, we have, presumptively at least, legislative authorization of the exercise of judicial power. The legislature has a choice of means. If it uses a court to act along the lines indicated, the presumption in favor of the exercise by such court of judicial power is not apparently rebutted by the fact that the court as interpreter is largely concerned in interpreting rules which expand in scope with the number of cases adjudicated upon. To regard the power of settling disputes between litigants before a court of compulsory arbitration as legislation, is to commit oneself to a prospect of privilegia in excelsis. To regard the power as administrative is to ignore essential facts, relative alike to organ, process, and effect, as a binding decision inter partes. If the power is neither legislative nor administrative, it is judicial.

The conclusion that a court of compulsory arbitration, engaged in making an award, is really exercising a judicial power, was opposed in the instant case on the authority of certain cases which I now propose to consider without dwelling unnecessarily upon the dangers of confusing dicta with decisions, and of drawing distinctions where there are no differences. The first case is that of Powell v. Apollo Candle Co. ${ }^{31}$ The case decided that the New South Wales legislature, though restricted in the area of its powers, within that area was unrestricted, and accordingly had plenary power to authorize the governor to levy a duty upon an article which, in the opinion of the collector, possessed properties in whole or in part capable of being used for a similar

${ }^{s 0} \mathrm{Cf}$. Vance, op. cit., supra note I7.

r (1885, P. C.) L. R. 1o A. C. $282,291$. 
purpose as a dutiable article-the duty to be fixed in proportion to the degree to which such unknown article approximates in its quality or uses to the dutiable article. In the course of the judgment in the case, the Board said:

"It is argued that the tax in question has been imposed by the Governor and not by the Legislature, who alone had power to impose it. But the duties levied under the Order in Council are really levied by the authority of the Act under which the Order is issued. The Legislature has not parted with its perfect control over the Governor, and has the power, of course, at any moment, of withdrawing or altering the power which they have entrusted to him."

From the point of view of the doctrine of the separation of powers, the judgment really amounts to no more than a statement that the governor, in exercising the power conferred upon him, was duly exercising an administrative power as ancillary to the carrying out of legislation. The case is no authority for the position that if a comparable power to that conferred upon the governor had been conferred upon a court (duly authorized to give a binding determination inter partes, after due process of hearing argument and evidence), the power would not have been judicial. Parliaments generally, and in particular parliaments with "plenary power," have a discretion as to choice of means. Whether the means be administrative or judicial can only be determined along the lines of "normal sequence," i. e., by reference to the structure of the organ, and the nature of the function as indicated by process and effect. I am quite unable to see that the case under immediate consideration has any authority, if indeed it has any relevancy, for the purposes for which it was cited in the principal case.

At p. 464 of the report of the principal case reference is made to a dictum of Lord Macnaghten: ${ }^{32}$

"I apprehend that it is not a function of a Court of Justice to enforce or give effect to moral obligations which do not carry with them legal or equitable rights."

The only remark I desire to make on this dictum in its application to the principal case is that a court of compulsory arbitration is really part of the machinery by means of which industrialists have been given, and are being given, a new status. The right to which such a court gives effect in deciding upon conditions of employment is a legal right by virtue of the Act, not a merely moral right. Herein lies the chief distinction between compulsory and voluntary arbitration. In one case a legal duty to submit to arbitration is imposed. In the other case, the arbitration is only by consent of parties; and if an award be made, the duty to comply with it has a conventional basis.

At p. 467 in the report of the principal case, in dealing with the contention that the Legislature had called the Commonwealth Court of Conciliation and Arbitration a "Court of Record," it was urged that

${ }^{82}$ Blackburn, Low \& Co. v. Vigors (I887, H. L.) L. R. I2 A. C. 53I, 543. 
mere language was not necessarily conclusive. Admittedly; but the authority, Fielding v. Thomas, ${ }^{33}$ deserves careful consideration. The case decided that the Nova Scotia House of Assembly had power to adjudicate that wilful disobedience to its order to attend in reference to a libel reflecting on its members is a breach of privilege and contempt, and to punish that breach by imprisonment. According to the head-note of the case, certain sections of the Colonial Act, "except so far as they may be deemed to confer any criminal jurisdiction, otherwise than as incident to the protection of its members, are intra vires of the local Legislature." The judgment ${ }^{34}$ reads :

"Their Lordships think that these sections were merely intended to give the House the power of a Court of Record for the purpose of dealing with breaches of privilege and contempt by way of committal."

It is difficult for me to see how Fielding $v$. Thomas could have been quoted as an authority for the position that what is called in a statute a court of record is not a court of record. A court of record may be such even though it has only a special and limited jurisdiction. In Halsbury's "Laws of England" it is said: 35

"All tribunals, however, are not courts, in the sense in which the term is here employed, namely, to denote such tribunals as exercise jurisdiction over persons by reason of a sanction of the law, and not merely by reason of voluntary submission to such jurisdiction. Thus, arbitrators, committees of clubs, and the like, although they may be tribunals exercising judicial functions, are not 'courts' in this sense of that term. On the other hand, a tribunal may be a court in the strict sense of the term although the chief part of its duties is not judicial. Parliament is a Court. Its duties as a whole are deliberative and legislative; the judicial duties are only partial. A court of investigation, like the coroner's court, is a court. The distinction appears to be not so much whether the particular tribunal is a court of justice, but whether it is a court in law. Many bodies are not courts, although they have to decide questions, and in so doing have to act judicially, in the sense that the proceedings must be conducted with fairness and impartiality, such as assessment committees, boards of guardians, the benchers of the Inns of Court when considering the conduct of one of their members, or the General Medical Council when considering questions affecting the position of a medical man. A meeting of a county council for granting music and dancing licenses is not a court, nor are justices at a licensing meeting sitting as a court of summary jurisdiction."

When a parliament with plenary powers expressly creates a "Court of Record," the strong presumption is that the Parliament means what it says. That presumption may be rebutted; but the general tenor of the Conciliation and Arbitration Acts could hardly be quoted even by the most sanguine advocate in rebuttal. Indeed, the language of the Acts is quite the other way.

At p. 482 of the report of the principal case, reference is made to

${ }^{23}[1896$, P. C. $]$ A. C. 600 .

st Id. 6I2.

${ }^{85} 9$ Halsbury, Laws of England, tit. Courts, at p. 9. 
Moses v. Parker. ${ }^{36}$ Section 25 of the Commonwealth Conciliation and Arbitration Acts reads:

"In the hearing and determination of every industrial dispute the Court shall act according to equity, good conscience, and the substantial merits of the case, without regard to technicalities or legal forms, and shall not be bound by any rules of evidence, but may inform its mind on any matter in such manner as it thinks just."

The head-note to the case of Moses v. Parker reads as follows:

"By Tasmanian Act No. Io of 1858 , disputes concerning lands yet ungranted by the Crown are referred to the Supreme Court, whose decision is to be final; and by sec. 8 the Court is directed to be guided by equity and good conscience only, and by the best evidence procurable, even if not required or admissible in ordinary cases, and not to be bound by strict rules of law or equity or by any legal forms. Held, that the Crown's prerogative to grant special leave to appeal is inapplicable to a decision so authorized."

The judgment reads: ${ }^{37}$

"What are the canons by which this Board is to be guided in advising Her Majesty whether the Supreme Court is right or wrong? It seems almost impossible that decisions can be varied except by reference to some rule; whereas the Court making them is free from rules. If appeals were allowed, the certain result would be to establish some system of rules; and that is the very thing from which the Tasmanian Legislature has desired to leave the Supreme Court free and unfettered in each case."

For present purposes, the passage in the judgment most likely to create any difficulty reads : ${ }^{38}$

"The [Supreme] Court has been substituted for the commissioners to report to the governor. The difference is that their report is to be binding on him. Probably it was thought that the status and training of the judges made them the most proper depositaries of that power. But that does not make their action a judicial action in the sense that it can be tested and altered by appeal. It is no more judicial than was the action of the commissioners and the governor."

On a first view, the case of Moses v. Parker appears as strong authority against the position which I have taken with respect to the nature of the power exercised by the Commonwealth Court of Conciliation and Arbitration when adjudicating between industrialists as to the terms and conditions of employment. But several points may be noted. (I) The decision was simply that the power exercised by the Tasmanian court in its special jurisdiction did not attract the prerogative right to grant leave to appeal. Whether a decision of a tribunal is absolutely final or not is clearly no criterion of the nature of the power which is exercised. (2) The ground of the decision was the intent of a statute (to which the Crown by consent of the governor was a party). Certain powers had been conferred upon the Tasmanian Supreme Court in terms from which it was inferred that the Crown prerogative to grant leave to appeal was

[s [rg6, P. C. $]$ A. C. 245.

${ }^{87}$ At p. 248.

"s Ibid. 
waived. Now, if we are to be guided by the intent of a statute, the fact that a tribunal of arbitration is expressly constituted a court of record must be given its due significance. In this connection, it is pertinent to refer again to the later decision of the House of Lords in Arlidge's Case, ${ }^{39}$ where it was held in substance, to quote the terse language of Dicey:

"The transference of jurisdiction from a Court to the Local Government Board is in itself prima facie evidence that Parliament intended that such jurisdiction should be exercised in accordance, not with the rules which govern judicial procedure, but with the rules which govern the fair transaction of business by the Local Government Board." 40

In Moses v. Parker the Privy Council held that the transference of an administrative function to an established judicature did not make the function judicial in the sense that it could be tested by appeal. The dictum that the function was "no more judicial than was the action of the commissioners and the governor" was clearly obiter. In any case, both decisions turned upon the interpretation of statutory language in jurisdictions where the doctrine of the separation of powers was not a constitutional limitation on legislative power, but a rule of statutory construction which might be deferred to when the language of a statute is ambiguous or imperfect. So understood, the cases are authorities, not for limiting the clear language of a statute, but for giving effect to it. In a jurisdiction where (as in the Commonwealth) the doctrine of the separation of the powers is a constitutional limitation upon the legislative power, and the legislature expressly creates a court of record, - cadit questio, though the power may be judicial sus generis, and the Court may have to be constituted in certain ways. It is often said that the person by whom a function is to be performed does not affect the nature of the function. The statement expresses a general rule; but it sometimes happens that the structure of an organ may be relevant for the purpose of indicating the nature of a power designed to be conferred. (3) That, under a particular section of a statute creating a court of compulsory arbitration, the court is required to act in good conscience and equity, and the substantial merits of the case, certainly implies a latitude of discretion in the working out of a code of principles. But it is little more than a recognition of practical necessities when the court is established to exercise a novel jurisdiction. The difference between Industrial Arbitration Acts and Anti-trust Acts in Australia is a difference not of kind but of degree. With respect to both sets of Acts, experience would have demonstrated, if prescience had been lacking, the need for a reasoned consistency of action in dealing with successive cases. Where some of the judges in the principal case appear to me to have erred is in the attempt to test the nature of the function exercised by a court of novel jurisdiction by reference to a set

${ }^{\circ}$ Local Gov't Board v. Arlidge [19I5, H. L.] A. C. 120.

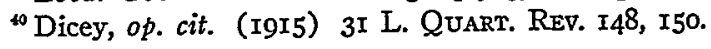


of ideas derived from the observation of the normal attributes of a jurisdiction long established. "The custom of Procrustes," we are told, "was to lay his guests upon his bed, and if they were too short for it to rack them to death; if too long, to cut off as much of their limbs as would make them short enough." It would seem from the principal case as though the ancient monster had been re-incarnated. A court may be a court though only in the pioneer stage. The failure to recognize the fact suggests a lack of historical mindedness, if not a pedantry of vision. It would seem as if the early history of common law and equity had been forgotten. If we come to realities and discard fiction, existing industrial courts in Australia are quite as much influenced in their judgment by pre-existing custom, usage, or precedent as early courts of common.law or equity. With the decision in Moses v. Parker I can only express my humble concurrence. But when an obiter dictum in that case is quoted to justify a decision as to the nature of a court of compulsory arbitration, I may be allowed, without questioning the accuracy of the dictum, to point out the difference between a jurisdiction conferred with the object of settling disputes "concerning lands yet ungranted by the Crown" with a jurisdiction designed to endure and, if we may credit Parliament with average common sense, to work out standard conditions of employment in such a way as to facilitate the settlement of disputes in future cases, or it may be to enable industrialists to agree without resort to litigation. A judge of an industrial court is driven by practical necessities towards the goal of a body of coherent principles; he is forever looking both behind him and before him. If he failed in this respect, his court would not be a court of industrial justice, but a tribunal of caprice. Instead of conducing to industrial stability, he would be an instrument for the creation of industrial unrest. He must aim at uniformity, consistency, certainty-an accordance between justice and the legitimate expectancy of the parties. If he were to take upon himself the part of a universal providence he would produce uncertainty, inconsistency, and chaos. (4) The fact that, in the course of the hearing and determining of an industrial dispute, a court may be expressly authorized to waive legal technicalities and the ordinary rules of evidence is no more than an indication of the common sense of the Legislature when establishing a court to exercise such a jurisdiction as is exercised by courts of compulsory arbitration to-day. In effect, the power to waive legal forms is permissive. As I have frequently stated when adjudicating in cases before the South Australian Industrial Court, the power should be exercised with great reserve. In actual experience, the rules of evidence, and even the rules of procedure so far as appropriate, have to be adhered to, for the simple reason that such rules are but crystallized experience as to the best way of doing justice to litigants in a lis. (5) The fact that an award may or may not be subject to appeal under the terms of a particular statute should be viewed in the light of experience 
of industrial arbitration in Australia. As there are state courts as well as the Commonwealth Court, several bodies of doctrine have been slowly evolved which are not homogeneous. Hence a great deal of industrial unrest due to a conviction on the part of either employers or employed, that if their dispute had been subject to adjudication by some other tribunal (Commonwealth or state), more favorable terms would have been awarded to the employers or to the employees, as the case may be. I doubt if there is any institution the need for which is more urgent and apparent in Australia to-day, than a Court of Industrial Appeals empowered to grant leave to appeal from existing courts of first instance. Such a court would be enabled to evolve a body of doctrine which would have a special degree of authority and of homogeneity.

I have dealt with the case of Moses $v$. Parker at some length, partly because it is a decision of the Privy Council, but mainly because it is the one case cited which appears to me to present any real difficulty as to the general argument of this article, so far as it applies to the principal case. It is pertinent to remark that Moses $v$. Parker was referred to only in support of one of the six judgments-a fact which may be taken as an indication or suggestion that the other judgments, though without exception based on arguments more or less in conflict with conclusions which I have stated, were held to derive no substantial support from the instant case. In a word, Moses $v$. Parker was only cited in support of one judgment, and then for a proposition which, on a discriminatory analysis, proves to be irrelevant. My lengthy discussion of it has been necessary, however, because of dicta which it contains which, on a first view, do appear to create real difficulties.

A decision of the Supreme Court of the United States, Wilson $v$. New, ${ }^{41}$ deserves reference because it might seem to support a dictum in the principal case which was stated in support of a conclusion which appears to me erroneous. The dictum in question is expressed by Isaacs and Rich, JJ., at p. 463 in the report of the principal case:

"It is always the statute which gives the arbitrator's opinion efficacy and stamps his decision with the character of a legal right or obligation."

With respect to the American case, Congress had passed an Act (the Adamson Law) to establish an eight-hour day for employers of carriers engaged in interstate and foreign commerce, and for other purposes: The Act was held to be intra vires. The decision must be read in the light of the special circumstances of the case, which included a nationwide dispute over wages between railroad companies and their train operatives, a prospect of a general strike, commercial paralysis, etc. The following dictum requires quotation: $:^{42}$

"We are of the opinion that the reasons stated conclusively establish that from the point of yiew of inherent power the act which is before us was clearly within the legislative power of Congress to adopt, and

\footnotetext{
11 (I9I7) 243 U. S. 332, 37 Sup. Ct. 298.
}

${ }_{243}$ U. S. 332,35 I. 
that in substance and effect it amounted to an exertion of its authority under the circumstances disclosed to compulsorily arbitrate the dispute between the parties by establishing as to the subject matter of that dispute a legislative standard of wages operative and binding as a matter of law upon the parties, - a power none the less efficaciously exerted because exercised by direct legislative act instead of by the enactment of other and appropriate means providing for the bringing about of such result. If it be conceded that the power to enact the statute was in effect the exercise of the right to fix wages where by reason of the dispute there had been a failure to fix by agreement, it would simply serve to show the nature and character of the regulation essential to protect the public right and safeguard the movement of interstate commerce, not involving any denial of the authority to adopt it."

As regards the Commonwealth Constitution, the validity of such an Act as that considered by the Supreme Court of the United States would probably not be called in question-the doctrine of parliamentary paramountcy having a greater scope in the Commonwealth than in the United States. But this does not solve the problems in the principal case. Granting that Parliament could "compulsorily arbitrate," it would not follow that it could not constitute a judicial tribunal to compulsorily arbitrate, or that such tribunal, in the exercise of its powers, would not be a part of the national judiciary. Indeed, the dictum cited suggests the contrary in as much as it refers to the possibility of the "enactment of other and appropriate means providing for the bringing about of such result." Such appropriate means might be administrative or judicial as Parliament might direct. As Professor Green writes: 43

"Separation of powers is not intended to prevent employing that organ of government whose characteristic mode of action is most appropriate for dealing with the situation. ... It has been held that as a public utility company is bound to serve at a reasonable rate, a court may be empowered, on the application of a party to whom such service has been denied, to determine the reasonable rate and to direct the rendering of service at that rate to that person for a limited time. But the court cannot be empowered on such an application to require the utility to adhere to the rate for all customers. As already explained that would be to take part in legislation. The court would be the mouthpiece of the legislature re-enacting the law in specific terms."

The reference to the various cases cited in support of dicta in the principal case with which I am unable to agree has been sufficiently comprehensive for the purposes of the present article. The language of judgments in the cases cited only creates difficulties when regarded in an undiscriminating way. It is only when we take language in relation to actual decisions, and the circumstances under which the decisions were given, that we can hope to discover an approximation to reasoned consistency in the development of law by judicial precedent. If we are to realize the significance of the statement that judges have

${ }^{4}$ Green, op. cit., 29 YaLE Law Journal, 369, 379. 
built better than they knew, we have to recognize the controlling value of that judicial intuition which is so often very imperfectly reflected in the language, or even in the formulated reasons, which are to be found in the text of judgments. I submit that neither the decisions to which I have referred, nor the rules of law implicit therein, derogate in any way from my general argument on the principal case. Briefly that argument is that the legislature expressly created a court of record, in the exercise of its power to provide for the settlement of industrial disputes by compulsory arbitration. The process described by the Act is clearly designed to be judicial, and would not be affected in its essential nature if the section allowing an unusual elasticity in the mode of conducting a hearing had been omitted-a process judicial sui generis. The judgments of the Court, as incidental to either arbitration or to the enforcement of awards, are binding on litigants in a lis inter partes. Both sets of provisions are valid. If, however, the judgments of the court are within the judicial power of the Commonwealth, the conclusion appears to follow irresistibly that the section of the Act relating to the tenure of the President was ultra vires in prescribing a seven years tenure of office. The judges held that if the Court could enforce its awards, it was, in doing so, exercising the judicial power of the Commonwealth within the meaning of Chapter III of the Constitution. I do not see how the conclusion can be questioned. It is true that a court-martial may be regarded as a judicial organ and yet not be within the meaning of Chapter III of the Constitution. But there are special reasons for this. Apart from any question of Imperial Army Acts, considerations of historical usage and invincible necessity combine to give to courtsmartial a unique character. It is incredible that the Imperial enactment creating the Commonwealth Constitution was designed to require that a court-martial should be constituted in accordance with principles affirmed for adjudication in respect to ordinary civil rights: The analogy to gaol discipline, though invidious, is legally apposite. A court-martial is an example of a judicial organ of the state which does not exercise "judicial power of the Commonwealth" within the meaning of Chapter III. Parliament itself is another example. The chief difficulty in the way of classing a compulsory arbitration court in the same category is that it adjudicates in relation to most important private civil rights-the right to freedom of contract, the right to unfettered discretion on the part of employers to employ whom they will, on such terms as may be agreed upon, etc. I return to the matter directly.

As to the general validity of the enforcing provisions of the Commonwealth Conciliation and Arbitration Acts the judges were unanimous. But whereas some judges thought that the Court itself as constituted could enforce, other judges held to the contrary. I subscribe to the opinion of the majority that the court as actually constituted could not enforce its own awards, but that even so, the awards could be enforced 
in courts of summary jurisdiction. By covering clause 5 of the Constitution, all laws made by the Commonwealth Parliament under the Constitution shall be binding on the courts, judges, and people of every state and of every part of the Commonwealth. I subscribe also to a dictum of Isaacs and Rich, JJ., to the effect that, even if no specific means of enforcement were provided in the Conciliation and Arbitration Acts, the common law would probably supply the defect. If the President of the Court had been appointed for life, the Court itself could have enforced. It would have been a federal court, properly constituted and endowed under the Act with original jurisdiction.

The outstanding question remains whether the Court in the exercise of the power of compulsory arbitration, acts in discharge of the judicial power of the Commonwealth. I have given my reasons for an affirmative answer to this question. The structure of the organ, the process, and even the effect, combine to stamp the body as a judicial, rather than a legislative or administrative organ. The organ is expressly called a court of record, and the President, though by the Act only entitled to hold office for seven years, can be re-appointed, and in any case cannot be removed otherwise than by an address of both houses. The limitation of seven years tenure goes to show an imperfect understanding of constitutional limitations by the Legislature, but in no way derogates from the obvious intention of the Legislature to create a judicial organ. Judicial process is defined by the Statute either expressly or indirectly by the power conferred to make rules of court. From the point of view of effect, the Court, even in making awards, adjudicates upon the civil right to claim relief. The fact that the nature of the relief may be left very much at large only goes to show that Parliament was embarking upon a difficult and unknown territory, and left it to the Court itself to work out in detail by a series of precedents (as to a large extent courts of common law and equity have done) the principles upon which relief could be granted. The Court, apart from the working out of those principles, and apart from the enforcing of provisions, had to interpret industrial legislation and the rules of court in the light of established rules of common law. It had also to give form and substance to the right to relief involved in the very concept of compulsory arbitration. Further, the Court, in the course of making successive awards and implicitly affirming certain principles, has been engaged in an increasing degree in the interpretation and application of those principles to changing conditions of time, place, and occupation. The Court was designed to be a judicial organ of the Commonwealth and to adjudicate upon the new civil right or status conferred upon industrialists by legislation. The limited tenure of the President may affect the validity of a particular section, but not the nature of the power designed to be conferred. That power, if the preceding argument be sound, was a part of the judicial power of the Commonwealth. The Court as in fact constituted could have, in my opinion, exercised neither the 
compulsory arbitral functions nor the enforcing functions. The dissonance of opinion in the judgments of the High Court was due, in my opinion, in a very large measure, to a desire not to give a decision which might invalidate existing awards. The desire is comprehensible. The fact that it was consummated along very different and often conflicting lines of argument goes to show, in my opinion, what a tangled web we weave when we start upon a process of taking liberties with the text of a statute, even though we may have the best of intentions. It would be doing less than justice to the language of the learned judges if we were to suppose them to be animated by a desire to crush or belittle what might be considered a parvenu. The real desire, as I understand most of the judgments, was ut res valeat. Unfortunately, there are limitations upon the expression of this desire. Whether I have expressed those limitations justly, I am well content to leave to the reader of the present article.

In concluding my remarks on the principal case, I wish to state that I think it would have been quite within the competence of the Commonwealth Legislature to create a tribunal for conciliation and arbitration presided over by a President with a limited tenure of office. But the arbitration would not be compulsory. The President would be an administrative officer whose services would be at the disposal of industrialists who should agree to avail themselves of his services for the purposes of settling difficulties which might arise from time to time as to the terms and conditions of employment. Any award by the President would have a conventional, not a judicial, basis. The power of the President, as a public official, would be neither legislative nor judicial, but administrative. If we were to say the power was quasi-judicial, we could only mean that an analogy to judicial process existed, and that the President, like many other administrative officials, must exercise his functions without fear or favor. 